\title{
PENGARUH STRES KERJA DAN LINGKUNGAN KERJA TERHADAP KINERJA KARYAWAN OPERATOR PDDIKTI DI LLDIKTI WILAYAH V YOGYAKARTA
}

\author{
THE EFFECT OF WORK STRESS AND WORK \\ ENVIRONMENT ON EMPLOYEES' PERFORMANCE OF \\ PDDIKTI OPERATORS IN LLDIKTI V YOGYAKARTA
}

\author{
Widarta \\ Universitas Mercu Buana Yogyakarta \\ E-mail: widarta@mercubuana-yogya.ac.id
}

\begin{abstract}
ABSTRAK
Penelitian ini bertujuan untuk mengetahui dan mendapatkan bukti empiris dalam memperoleh jawaban atas pengaruh secara bersama-sama dan parsial stres kerja dan lingkungan kerja terhadap kinerja karyawan operator PDDIKTI di LLDIKTI wilayah V Yogyakarta. Dalam penelitian ini, teknik pengumpulan data dilakukan dengan metode survey. Adapun sumber data yang digunakan adalah data primer menggunakan instrumen quesioner dan data sekunder menggunakan dokumentasi dan studi pustaka yang dibukukan. Sampel dalam penelitian ini sebanyak 84 karyawan operator PDDIKTI di PTS LLDIKTI wilayah $\checkmark$ Yogyakarta. Pengujian data dalam penelitian ini menggunakan analisis regresi dengan bantuan software SPSS 21 for Window. Sehingga diperoleh, variabel stres kerja dan lingkungan kerja berpengaruh positif terhadap kinerja karyawan operator PDDIKTI LLDIKTI Wilayah V Yogyakarta dengan nilai koefisien determinasi sebesar 0,435. Dimana sebesar 43,5\% stres kerja dan lingkungan kerja memberikan dampak terhadap kinerja karyawan operator PDDIKTI LLDIKTI wilayah V Yogyakarta.
\end{abstract}

Kata Kunci: stres kerja, lingkungan kerja, kinerja karyawan

\begin{abstract}
This study aims to determine and obtain empirical evidence in obtaining answers to the effects of joint and partial work stress and work environment on the performance of PDDIKTI operator employees in LLDIKTI region $V$ Yogyakarta. In this study, the data collection techniques were done by using survey method. The sources of the data used are primary data using questionnaire instruments and secondary data using documentation and recorded library research. The sample in this study were 84 employees of PDDIKTI operators in PTS LLDIKTI region $V$ Yogyakarta. The data in this study are tested by using regression analysis with the help of SPSS 21 for Window software. So that it is obtained, work stress and work environment variables have a positive effect on the performance of employees of PDDIKTI LLDIKTI Region $V$ Yogyakarta employees with a coefficient of determination of 0.435 . Where $43.5 \%$ of work stress and the work environment have an impact on the performance of employees of the PDDIKTI LLDIKTI region $V$ Yogyakarta.
\end{abstract}


Keywords: work stress, work environment, employee performance

\section{PENDAHULUAN}

Unsur sumber daya manusia dalam organisasi yang mempunyai kedudukan strategis ini karena manusialah yang mengetahui input-input apa yang perlu diambil dari lingkungan dan bagaimana untuk mendapatkan dan atau menangkap input-input tersebut, teknologi dan cara apa yang tepat untuk mengolah keinginan pasar atau publik atau lingkungan. Tuntutan profesionalitas kerja yang semakin tinggi menimbulkan banyaknya tekanantekanan yang harus dihadapi individu dalam lingkungan kerja di perusahaannya. Selain tekanan yang berasal dari lingkungan kerja, juga target kerja yang diinginkan oleh perusahaan sangat potensial menimbulkan tekanan. Tekanan yang timbul dan berlangsung terus menerus berpotensi menimbulkan kecemasan.

Stres kerja adalah perasaan yang menekan atau merasa tertekan yang dialami oleh karyawan dalam menghadapi pekerjaan (Mangkunegara, 2003). Timbulnya stres karyawan dapat dibedakan menjadi dua kategori yaitu : Stres kerja on the job dan off the job. Stres on the job adalah stres yang disebabkan oleh masalah-masalah yang terjadi di dalam perusahaan meliputi faktor : pekerjaan, hubungan kerja, organisasi. Stres kerja off the job adalah stres karyawan yang disebabkan oleh masalah-masalah yang terjadi diluar pekerjaan. Penyebab stres kerja off the job antara lain : faktor keuangan, keluarga, dan masyarakat (Dewi, 2014). Artinya stres muncul pada saat karyawan tidak mampu memenuhi apa yang menjadi tuntutan-tuntutan pekejaan.

Ketidakjelasan apa yang menjadi tanggung jawab, kekurangan waktu untuk menyelesaikan tugas, tidak ada fasilitas untuk menjalankan pekerjaan, adanya hambatan sistem yang menjadi terhambatnya pekerjaan, dan sebagainya. Dalam jangka pendek, stres yang dibiarkan begitu saja tanpa penanganan yang serius dari perusahaan membuat karyawan menjadi tertekan, tidak termotivasi dan bahkan frustasi yang menyebabkan tidak bisa bekerja secara optimal sehingga kinerjanya pun terganggu. Dalam jangka panjang karyawan yang tidak dapat menahan stres kerja maka ia tidak akan mampu bekerja lagi sehingga berimbas pada kinerja karyawan yang sangat menurun dan pada akhirnya karyawan tersebut akan mengundurkan diri (turnover).

Kinerja karyawan dipandang perlu dalam organisasi/perusahaan karena dapat menentukan hidup dan matinya suatu perusahaan. Kinerja itu sendiri dapat berdampak positif bila terdapat campur tangan pihak pimpinan (manajer), sehingga stres dapat ditanggulangi atau sebagai senjata dalam mendongkrak kinerja karyawan. Tuntutan tugas merupakan merupakan faktor yang berkaitan dengan pekerjaan seseorang dan dapat memberikan tekanan pada orang jika kecepatan tuntutan tugas dirasakan berlebihan, selain itu tuntutan tugas dapat meningkatkan kecemasan dan stres (Robbins, 2001).

Stres atau tekanan jiwa merupakan keadaan wajar, terbentuk dalam diri manusia sebagai respon terhadap setiap hasrat atau kehendak, maka dari itu stres tidak mungkin dihindari, karena merupakan bagian dari kehidupan sehari - hari pada manusia. Keadaan ini tentu saja akan menuntut energi yang lebih besar, akan tetapi menurut Davis \& Werther (1996). Sejalan dengan meningkatnya stres, prestasi cenderung naik karena stres membantu individu untuk mengarahkan segala sumber daya dalam memenuhi standar kerja, namun pada tingkatan tertentu stres kerja yang meningkat akan menurunkan kinerja karyawan.

Stres kerja di dalam dunia pendidikan khususnya Perguruan Tinggi (PT) sangat terasakan oleh para tenaga admin atau operator perguruan tinggi. Hal ini terkait dengan pelaporan semesteran yang wajib bagi setiap PT untuk melaporkan kegiatan akademiknya kepada DIKTI dan LLDIKTI, Dahulunya program tersebut bernama Evaluasi Program Studi Berdasarkan Evaluasi Diri (EPSBED), dan sekarang berganti nama lagi menjadi Pangkalan data perguruan tinggi (PDDIKTI). 
Dalam hal penyampaian Laporan EPSBED, berdasarkan Surat Edaran Dikti Nomor : 0543/E1.2/PL/2015 tentang feeder PDDIKTI, bahwa mulai laporan 2014-2 "wajib" menggunakan sistem baru dengan nama "feeder PDDIKTI" sebagai jembatan antara sistem akademik yang dimiliki oleh perguruan tinggi dengan Pangkalan Data Pendidikan Tinggi (PDDIKTI) sebagai database DIKTI. Saat ini istilah laporan EPSBED dikenal sebagai laporan PDDIKTI (sebelumnya PDPT)

Pangkalan Data Pendidikan Tinggi (PDDIKTI) merupakan kumpulan data penyelenggaraan pendidikan Tinggi seluruh Perguruan Tinggi yang terintegrasi secara nasional terdokumentasi pada laman http://forlap.dikti.go.id. PDDIKTI menjadi salah satu instrument pelaksanaan penjaminan mutu.

Dalam pasal 56 ayat 2 UU No. 12 Tahun 2012 tentang Pendidikan Tinggi menyebutkan bahwa Pangkalan Data Pendidikan Tinggi sebagaimana dimaksud pada ayat (1) berfungsi sebagai sumber informasi bagi: (1) Lembaga akreditasi, untuk melakukan akreditasi Program Studi dan Perguruan Tinggi;(2) Pemerintah, untuk melakukan pengaturan, perencanaan, pengawasan, pemantauan, dan evaluasi serta pembinaan dan koordinasi Program Studi dan Perguruan Tinggi;dan (3) Masyarakat, untuk mengetahui kinerja Program Studi dan Perguruan Tinggi. Ditambah peraturan pemerintah Nomor 4 tahun 2014 tentang penyelenggaran Pendidikan Tinggi, menyatakan bahwa pelaporan kegiatan akademik merupakan kewajiban setiap perguruan tinggi kepada Direktorat Jenderal Pendidikan Tinggi (DIKTI) melalui Pangkalan Data Perguruan Tinggi (dahulu EPSBED) yang harus dilakukan setiap semester.

Lembaga Layanan Pendidikan Tinggi (LLDIKTI) sebagai kepanjangan tangan dari Kementerian Riset Teknologi dan Perguruan Tinggi (Kemristek DIKTI), dalam rangka aspek penyelenggaraan, pengawasan, pembinaan, dan evaluasi perguruan tinggi dilakukan berdasarkan data dan status perguruan tinggi yang terekam pada pangkalan perguruan tinggi (PDDIKTI). Tindak lanjut dari peraturan pemerintah tersebut, apabila sebuah perguruan tinggi sampai tidak melaporkan kegiatan akademiknya maka akan menerima sangsi yang berat berupa akan men"non-aktif"kan perguruan tinggi tersebut atau penutupan program studi atau bahkan penutupan institusi perguruan tingginya. Sebelum penutupan ada sangsi-sangsi lain yang harus diterima oleh PT berupa penutupan atau penundaan, antara lain :

a. Pengusulan akreditasi ke BAN-PT (Badan Akreditasi Nasional Perguruan Tinggi)

b. Re-akreditasi program studi tertunda atau tidak ada visitasi akreditasi

c. Pembukaan program studi baru

d. Pemberian sertifikasi dosen

e. Pemberian hibah-hibah (penelitian, dan lain-lain)

f. Berbagai macam beasiswa mahasiswa dihentikan

g. Berbagai beasiswa studi lanjut maupun pelatihan yang diadakan dihentikan.

Sedemikian pentingnya peran dan fungsi operator serta beratnya sangsi bila perguruan tinggi sampai tidak melaporkan kegiatan akademiknya membuat tekanan berat bagi para operator PDDIKTI. Harus menyelesaikan pelaporan sesuai dengan waktu yang telah ditentukan, dengan dukungan sumber data yang akurat serta seorang operator harus mampu dan mau untuk terus belajar mengikuti software aplikasi DIKTI yang selalu berkembang.

Indikator yang secara umum menuntut seorang operator perguruan tinggi harus bekerja ekstra keras untuk dapat menyelesaikan tugasnya dalam membuat pelaporan secara akurat, diantaranya :

a) Beban kerja

Beban kerja yang cukup berat sangat dirasakan, karena cakupan isian dalam feeder DIKTI ysangat banyak, hampir semua transaksi akademik baik dosen maupun mahasiswa harus terekap dalam pelaporan, mahasiswa sejak mulai masuk sebagai mahasiswa baru sampai dengan kelulusan pendataanya harus lengkap termasuk 
didalamnya proses akademiknya. Demikian juga dengan dosen harus jelas dalam menjalankan Tridhama perguruan tinginya.

b) Kondisi kerja, mengerjakan pelaporan harus ditupang dengan kondisi kerja yang baik. Bila sekitar ruang kerja sudah tidak nyaman, misalnya ruang terlalu panas, ruang kerja sangat ramai dan banyak lagi, akan membuat operator tidak konsentrasi. Akhinya pendataan pelaporan pun akan menurun kualitasnya.

c) Konflik peran, tuntutan akan kualitas dan akurasi pelaporan membuat operator berusaha sekuat tenaga untuk membuat laporan dengan sebaik mungkin. Ini mengakibatkan kadang sampai lebur-lembur dan bahkan di bawa ke rumah. Tetapi kadang pimpinan (atasan) tidak tahu akibatnya perberlakuan operator sama dengan karyawan lainnya khususnya dalam penggajian.

d) Pengembangan karier, masa depan opertor kadang tidak jelas dalam perjenjangan. Hal ini terjadi karena sifat pekerjaan dengan spesifikasi khusus yang harus dimiliki oleh karyawan, selain faktor ketelitian juga kemampuan adaptasi terhadap sistem yang baru (aplikasi) yang sering kali mengalami perkembangan dan tambahan menu-menunya.

e) Hubungan interpersonal, hubungan yang tidak harmonis berakibat kepada hambatan perolehan sumber data yang dapat dipertanggungjawabkan. Komunikasi dengan atasan maupun unit-unit kerja yang lain berpengaruh kepada ketepatan waktu pelaporan khususnya dan juga akurasi data.

f) Stres kerja operator PDDIKTI terasakan juga pada saat terjadi hal-hal yang diluar dugaan kita, misalnya komunikasi yang tidak harmonis sampai dengan terjadinya kekerasan dan juga perebutan peralatan yang sangat terbatas misalnya akses internet yang minimal dan laptop yang tidak memenuhi syarat

Indikator lingkungan kerja operator PDDIKTI, sangat mempengaruhi hasil atau kinerja dari operator PD DIKTI, lingkungan kerja fisik berupa kenyamanan dalam bekerja, tata ruang, pencahayaan ruangan, keamanan, kebisingan dan sebagainya. Juga lingkungan kerja non fisik yang berupa bagaimana hubungan yang harmonis dengan pimpinan, sesama karyawan dan juga adanya penghargaan bagi prestasi karyawan.

Indikator kinerja karyawan, menyangkut kontribusi operator PD DIKTI terhadap jalanya roda akademik bagi perguruan tinggi. Bagaimana kualitas pelaporan, kuantitas pekerjaan, kemampuan mengerjakan dalam waktu yang tepat, juga adanya pengawasan dan hubungan yang baik dengan seluruh komponen institusi. Tuntutan dan tanggung jawab kerja operator PDDIKTI sebuah perguruan tinggi, harus menguasai sistem aplikasi bahkan sampai "ruh"nya. Tergambarkan aplikasi pelaporan PDDIKTI sejak pertama kali wajib diisikan sejak tahun 2002 semester 1 dengan nama "layar biru" dengan dasar SK034/PT, kemudian berubah menjadi winEpsbed, Web loader, Web entry, epsbed, PDPT, forlap dengan ekstensi dbf, csv, xml, dan akhirnya sekarang yang berlaku menjadi Feeder PDDIKTI. Faktor lain yang mempengaruhi kinerja karyawan adalah lingkungan kerja. Lingkungan kerja itu mencakup hubungan kerja antara bawahan dan atasan serta lingkungan fisik tempat karyawan bekerja. Lingkungan kerja mempunyai pengaruh langsung terhadap para karyawan dalam melaksanakan tugasnya di dalam perusahaan (Ahyani, 1994).

Lingkungan kerja di bagi menjadi dua, yaitu lingkungan kerja fisik dan lingkungan kerja non fisik. Lingkungan kerja fisik adalah segala sesuatu yang ada disekitar pekerja yang dapat dirasakan serta dapat mempengaruhi dirinya dalam menjalankan tugas-tugas yang dibebankan. Sedangkan lingkungan non fisik adalah segala sesuatu yang ada disekitar pekerja dan tidak dapat dirasakan oleh panca indera manusia namun dapat mempengaruhi dirinya dalam menjalankan tugas-tugas yang dibebankannya (Nitisemitro, 1999)

Lingkungan kerja sangat berpengaruh pada kinerja karyawan. Menurut Sedarmayanti (2009), lingkungan kerja adalah keseluruhan alat perkakas dan bahan yang dihadapi lingkungan sekitar dimana seseorang bekerja, metode kerjanya, serta peraturan kerjanya 
baik sebagai perseorangan maupun kelompok. Lingkungan kerja ini perlu mendapat perhatian dari manajemen. Meskipun lingkungan kerja ini tidak berpengaruh langsung dengan kegiatan produksi tetapi lingkungan kerja mempunyai pengaruh langsung kepada karyawan. Lingkungan kerja yang nyaman akan meningkatkan kualitas kinerja, sebaliknya jika lingkungan kerja kurang nyaman akan menurunkan motivasi kerja yang akhirnya akan berdampak pada penurunan kinerja karyawan dalam organisasi.

Baik lingkungan kerja fisik maupun kondisi non fisik sangat berpengaruh pada kualitas kerja seorang operator PDDIKTI. Lingkungan kerja yang nyaman dan komunikasi yang serasi antara operator PDDIKTI dengan unit yang lain sangat diperlukan. Mengingat sumber data yang diinputkan untuk pelaporan pasti berasal dari unit lain dan harus dikoordinasikan dengan pimpinan perguruan tinggi. Komponen utama yang dilaporkan adalah data mahasiswa, transaksi perkuliahan serta data dosen. Artinya operator akan dapat bekerja dengan baik atau untuk berkinerja baik harus mempunyai lingkungan kerja yang nyaman, komunikasi dengan pimpinan dan bidang-bidang yang lain sehingga akan terlayani dalam usaha memperoleh sumber data pelaporan dalam setiap semesternya. Tekanan kerja dan lingkungan kerja sangat menentukan kinerja dari karyawan operator PDDIKTI

Menurut Mangkunegara (2011), kinerja adalah hasil kerja secara kuantitas dan kualitas yang dicapai oleh seseorang karyawan dalam melaksanakan tugasnya sesuai dengan tanggung jawab yang diberikan kepadanya. Adapaun pengukuran kinerja karyawan dalam penelitian berdasakan Mangkunegara (2000) adalah kualitas kerja, kedisiplinan, kemampuan, komunikasi dan inisiatif.

Operator PDDIKTI di masing-masing perguruan tinggi mempunyai peran sentral dalam berlangsungan penyelenggaraan pendidikan tinggi. Peraturan pemerintah yang mewajibkan setiap perguruan tinggi melaporkan kegiatan akademiknya dalam setiap semester dengan aplikasi software yang terus berkembang (cenderung berubah-ubah) menjadikan operator PDDIKTI wajib dan harus mampu menyesuaikan dan menyelesaikannya.

Berbagai tuntutan akan sangsi bila tidak membuat laporan ke DIKTI, ketepatan (akurasi) data yang dilaporkan serta terbatasnya waktu benar-benar membuat operator PD DIKTI tertekan kerjanya, dan berpengaruh langsung terhadap kinerja operator tersebut. Pimpinan PT (Perguruan Tinggi) pasti akan setiap saat menanyakan perkembangan pelaporannya, sementara kalau data dari unit penyulai tidak lengkap (tidak akurat) kelak akan menjadi masalah. Hal ini benar-benar membuat stres para operator PT, sebab bila pelaporan yang disampaikan ke laman DIKTI tidak akurat pasti akan kena validasi dari aplikasi PDDIKTI, dan juga akan dipertanyakan oleh LLDIKTI. Sementara pihak pimpinan PT tahunya kesalahan operator. Akibatnya operator yang pasti akan dituntut untuk segera menyelesaikannyai, karena kalau sampai tidak diperbaiki akan berdampak negatif pada institusi perguruan tinggi. Tekanam berat dan bertubi-tubi mempengaruhi kinerja dari karyawan operator PD DIKTI justru akan menurun, karena terlalu besar beban yang harus ditanggung.

Lingkungan kerja dari institusi perguruan tinggi faktor penentu dalam kinerja karyawana operator PDDIKTI. Aturan akademik, suasana akademik, komunikasi antar unit kerja termasuk di dalamnya hubungan dengan atasan/pimpinan sebagai penyedia (sumber) data sangat mendukung agar kerja operator PDDIKTI dapat menyelesaikan tugas-tugasnya dalam pelaporannya secara akurat dan dapat dipertanggungjawabkan serta sesuai waktu yang sudah ditentukan. Adanya lingkungan kerja utamanya komunikasi yang baik dengan atasan, dan unit-unit penyedia data yang baik akan membuat operator nyaman dalam menyelesaikan pelaporannya, dan karena lingkungan yang nyaman menjadikan kinerja karyawan operator juga akan menjadi lebih baik.

Berdasarkan paparan di atas, maka tujuan dalam penelitian ini untuk mengetahui dan mendapatkan bukti empiris dalam memperoleh jawaban atas pengaruh secara bersamasama dan parsial stres kerja dan lingkungan kerja terhadap kinerja karyawan operator PDDIKTI di LLDIKTI wilayah V Yogyakarta. 


\section{METODE PENELITIAN}

Jenis Penelitian

Jenis penelitian yang digunakan dalam penelitian ini adalah survei dengan pendekatan deskriptif kuantitatif, dimana fenomena yang akan diteliti adalah kejadian yang telah berlalu atau sedang berlangsung, dalam konteks ini adalah proses pembelajaran. Sugiyono (2008: 6) mengungkapkan bahwa metode penelitian survei digunakan untuk mendapatkan data dari tempat tertentu yang alamiah (bukan buatan), tetapi peneliti melakukan perlakuan dalam pengumpulan data.

Sugiyono (Nuryadi \& Rahmawati, 2008) mengungkapkan bahwa metode penelitian survei digunakan untuk mendapatkan data dari tempat tertentu yang alamiah (bukan buatan), tetapi peneliti melakukan perlakuan dalam pengumpulan data, misalnya dengan mengedarkan kuesioner, test, wawancara terstruktur dan sebagainya (perlakuan tidak seperti dalam penelitian eksperimen). Selanjutnya, Arikunto (2010: 3) menjelaskan bahwa dalam penelitian deskriptif, peneliti tidak memberikan perlakuan khusus kepada obyek yang diteliti namun memaparkan atau menggambarkan keadaan, kondisi atau peristiwa yang terjadi secara apa adanya.

\section{Desain Penelitian}

Desain yang digunakan dalam penelitian ini adalah Survei Descriptive Design. Sebagaimana yang dikemukakan oleh Nazir (Nuryadi, dkk.,2017) terdapat berbagai langkah yang harus dilaksanakan dalam penelitian ini, antara lain: (1) memilih dan merumuskan masalah. Masalah yang akan diteliti yaitu bagaimana pelaksanaan penerapan model pembelajaran berbasis proyek dan bagaimana persepsi siswa tentang penerapan model pembelajaran berbasis proyek dari aspek kesesuaian model pembelajaran, kreativitas belajar siswa, dan hasil belajar siswa; (2) menentukan tujuan dari penelitian yang akan menjawab rumusan masalah; (3) memberikan batasan-batasan peneltian dan menentukan sampel; (4) menyusun tinjauan pustaka yang kuat; (5) menyusun instrument pengumpulan data; (6) melakukan pengumpulan data, teknik pengumpulan data yang digunakan adalah lembar observasi keterlaksanaan pembelajaran, kuesioner yang telah diujicobakan terlebih dahulu.

\section{Teknik Pengumpulan Data}

Pengumpulan data yang lengkap yang berhubungan dengan penelitian ini dilakukan dengan metode survey. Dalam penelitian ini, penentuan data mendasarkan pada teknik sampling. Dimana teknik sampling jenisnya ada 2 (dua) yaitu random sampling dan non random sampling.

Menurut Hasan (2005), random sampling (sampling probabilitas) merupakan cara pengambilan sampel dimana semua objek atau elemen populasi memiliki kesempatan yang sama untuk dipilih sebagai sampel. Sedangkan non random sapling (sampel nonprobabilitas) yaitu cara pengambilan sampel dimana semua objek atau elemen populasinya tidak memiliki kesempatan yang sama untuk dipilih sebagai sampel.

\section{Teknis Analisis Data}

Data yang diperoleh dalam penelitian ini adalah berupa kuesioner sebagai data primer dan data kajian pustaka sebagai data sekunder. Metode penelitian ini menggunakan metode kuantitatif karena data penelitian berupa angka-angka angket dan dianalisis menggunakan statistik. Adapun teknik analisis data yang dilakukan adalah sebagai berikut :

1. Tahap persiapan

Setelah data dikumpulkan menggunakan kuesioner (data primer) dan data sekunder dengan kajian pustakan, data yang sudah terkumpul melalui kuesioner dan data-data pendukung selanjutnya dimasukan dan diolah untuk dianalisis. Kuesioner yang dibagikan disertai surat permohonan pengisian kuesioner dan penjelasan mengenai halhal yang berkaitan dengan penelitian. Skala yang digunakan dalam kuesioner adalah 
skala likert dengan jawaban bertingkat dalam lima kategori mulai dari penilaian sangat setuju sampai penilaian yang sangat tidak setuju.

2. Tahap Tabulasi

Tahap ini mencakup skoring, yaitu tahap pemberian skor pada hasil kuesioner sesuai ketentuan yang telah ditetapkan sebelumnya. Variabel memiliki beberapa dimensi, selanjutnya dimensi dari masing-masing terdiri dari beberapa indikator yang dipresentasikan ke dalam pertanyaan-pertanyaan. Dari pertanyaan tersebut dinilai berdasarkan skala Likert 5 (lima) jenjang $(1-5)$. Urutan dalam skala ini menggunakan lima angka penilaian yaitu :

Tabel 1. Bobot penilaian skala Likert

\begin{tabular}{lc}
\hline \multicolumn{1}{c}{ Skala } & Bobot \\
\hline Sangat Tidak Setuju (STS) & 1 \\
Tidak Setuju (TS) & 2 \\
Netral (N) & 3 \\
Setuju (S) & 4 \\
Sangat Setuju (ST) & 5 \\
\hline
\end{tabular}

Penilaian didasarkan pada jawaban atau persepsi responden terhadap pertanyaan/pernyataan yang diajukan sesiuai dengan kenyataan yang ada. Skor dari masing-masing pertanyaan/pernyataan dalam satu dimensi dijumlahkan menjadi skor untuk dimensi tersebut. Selanjutnya skor variabel adalah merupakan akumulasi dari skor dimensidimensi tersebut. Kemudian skor keseluruhan dari tiap-tiap angket dicari persentasenya kemudian dikualifikasikan dalam interval persentase keberhasilan dengan kategori sebagai berikut:

Tabel 2. Kriteria interval presentasi keberhasilan

\begin{tabular}{ccc}
\hline No & Interval & Skor \\
\hline 1. & $0 \%-20 \%$ & Sangat Kurang \\
2. & $21 \%-40 \%$ & Kurang Baik \\
3. & $41 \%-60 \%$ & Cukup Baik \\
4. & $61 \%-80 \%$ & Baik \\
5. & $81 \%-100 \%$ & Sangat Baik \\
\hline
\end{tabular}

\section{Tahap Penerapan Data}

Analisa data dilakukan berdasarkan hasil dari tiap-tiap instrumen yang telah diperoleh. ketika sudah diketahui persebaran data masing-masing instrumen dalam bentuk persentase, sehingga untuk mengetahui dan mendapatkan bukti empiris dalam memperoleh jawaban atas pengaruh secara bersama-sama dan parsial stres kerja dan lingkungan kerja terhadap kinerja karyawan operator PDDIKTI di LLDIKTI wilayah V Yogyakarta.

Untuk mengetahui apakah terdapat pengaruh dari variabel-variabel pada faktor kinerja karyawan dilakukan analisis regresi linier berganda. Pengujian hipotesis dilakukan dengan persamaan regresi berganda, dengan rumus:

$$
Y=a+b 1 X 1+b 2 \times 2+e
$$

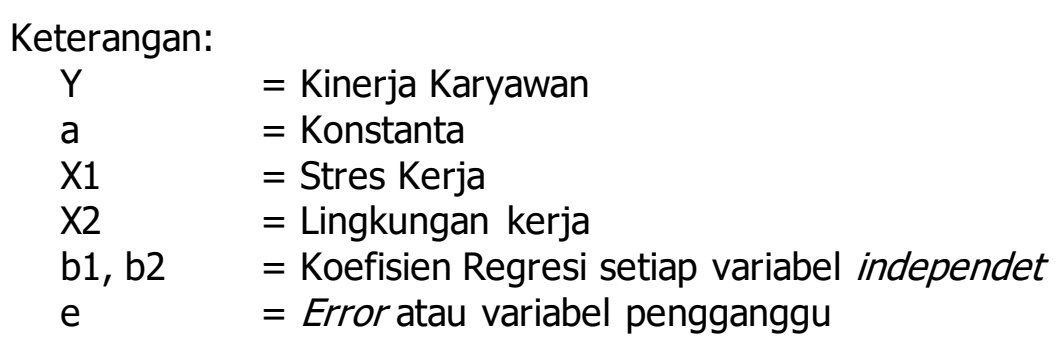


Di dalam analisis regresi linier berganda meliputi analisis uji $\mathrm{F}$ (simultan) dan analisis uji $\mathrm{t}$ (parsial). Dalam penelitian ini juga meliputi analisis koefisien determinasi, menggunakan SPSS versi 21 for windows

\section{Validasi dan Reliabilitas}

Menurut Anderson, dkk (Arikunto, 2010: 80) menyebutkan "Sebuah tes dikatakan valid apabila tes tersebut mengukur apa yang hendak diukur". Pengujian validitas instrumen pada penelitian ini adalah dengan validitas isi dan konstruk. Dalam penelitian ini menggunakan validitas isi, maka dapat digunakan pendapat dari para ahli (judgment experts). Kuesioner dibuat berdasarkan teori tertentu, kemudian dikonsultasikan kepada para ahli untuk mendapatkan tanggapan dan evaluasi secara sistematis atas kuesioner yang telah dibuat. Para ahli tersebut adalah dosen ahli yang sesuai dengan bidang penelitian terkait. Dalam prosesnya, dosen meneliti dan mencermati setiap butir pertanyaan/ pernyataan agar sesuai dengan kajian teori dan layak untuk digunakan. Instrumen penelitian diteliti dan dilakukan beberapa kali revisi terhadap butir-butir pertanyaan/ pernyataannya. Berdasarkan validitas isi yang dilakukan oleh dosen ahli didapatkan hasil bahwa instrumen penelitian layak digunakan dengan perbaikan kemudian dilakukan uji validitas konstruk.

Selain menggunakan validitas isi, instrumen dalam penelitian ini juga diuji dengan validitas konstruk, yaitu dilakukan dengan menguji-cobakan instrumen tersebut pada responden yang mempunyai karakteristik sama, kemudian hasil masing-masing item kuesioner dikorelasikan dengan skor total (korelasi Product Moment).

Jumlah sampel diambil adalah sebesar 84 responden dari Perguruan Tinggi Swasta (PTS) yang ada di lingkungan LLDIKTI Wilayah V Yogyakarta. Selanjutnya nilai $r_{x y}$ dibandingkan dengan $r_{\text {tabel }}$ dengan taraf signifikan 5\%. Jika $r_{x y}$ lebih besar atau sama dengan $r_{\text {tabel }}$ maka item tersebut dinyatakan valid. Namun apabila nilai $r_{x y}$ lebih kecil dari $r_{\text {tabel }}$ pada taraf signifikan $5 \%$ maka item tersebut dinyatakan tidak valid. Item atau butir yang tidak valid dihilangkan/ diganti dan item yang valid dapat digunakan untuk penelitian. Untuk $r_{\text {tabel }}$ dengan responden sebanyak 84 siswa $(N=84, \mathrm{DF}=82)$ dengan taraf kepercayaan $95 \%$ yang diperoleh adalah sebesar 0,212 .

\section{Uji Asumsi Klasik}

Uji asumsi klasik harus dilakukan untuk menguji layak tidaknya model analisis regresi yang digunakan dalam penelitian. Uji ini meliputi : uji normalitas, uji multikolinearitas dan uji heteroskedastusitas.

\section{Uji Normalitas}

Uji normalitas bertujuan untuk menguji apakah dalam model regresi, variabel terikat, variabel bebas atau keduanya mempunyai distribusi normal atau tidak. Model regresi yang baik adalah memiliki distribusi data normal atau penyebaran data statistik pada sumbu diagonal dari grafik distribusi normal (Ghozali, 2009). Dalam penelitian ini uji normalitas didetaksi dengan melihat penyebaran data pada sumbu diagonal dari grafik normal p-plot. Adapun pengambilan keputusan didasarkan pada : (a) Jika data menyebar di sekitar garis diagonal dan mengikuti arah garis diagonal, atau grafik histogram menunjukkan pola distribusi normal, maka model regresi memenuhi asumsi klasik;(2)Jika data menyebar menjauh dari garis diagonal dan tidak ada titik yang mengikuti arah garis diagonal, maka regresi tidak memenuhi asumsi normalitas.

\section{Uji Multikolinieritas}

Uji multikolinieritas bertujuan untuk menguji apakah dalam model regresi ditemukan adanya korelasi antar variabel bebas (independen). Model regresi yang baik seharusnya tidak terjadi korelasi di antara variabel independen. Suatu model regresi dikatakan bebas dari multikolinieritas apabila nilai tolerance $>0,1$ (Ghozali, 2009). Untuk mendeteksi ada 
atau tidaknya multikolonieritas di dalam model adalah sebagai berikut: (1) Nilai R2 yang dihasilkan oleh suatu estimasi model regresi empiris sangat tinggi, tetapi secara individual variabel-variabel independen banyak yang tidak signifikan mempengaruhi variabel dependen; (2) Menganalisis matrik korelasi variabel-variabel independen. Jika ada korelasi yang cukup tinggi (umumnya di atas 0,90) maka hal ini merupakan indikasi adanya multikolonieritas; dan (3) Melihat nilai tolerance dan Variance Inflation Factor (VIF). Kedua ukuran ini menunjukkan variabel independen mana yang dijelaskan oleh variabel independen lainnya.

\section{Uji Heteroskedastisitas}

Bertujuan untuk menguji apakah model regresi terjadi ketidaksamaan varian dari satu pengamatan ke pengamatan yang lain (Ghozali, 2009). Cara mendeteksinya dengan melihat ada tidaknya pola tertentu pada grafik scatterplot antara Sresid dsn Zpred, dimana sumbu Y adalah $Y$ yang telah diprediksi, dan sumbu $X$ adalah residu ( $Y$ prediksi - $Y$ sesungguhnya) yang telah di-standarized (Ghozali, 2009). Dasar analisisnya adalah: (1) Jika titik-titik yang ada membentuk pola tertentu yang teratur, maka mengindikasikan telah terjadi heteroskedastisitas; dan (2) Jika tidak ada pola yang jelas, serta titik-titik menyebar di atas dan di bawah angka 0 pada sumbu Y, maka tidak terjadi Heteroskedastisitas.

\section{HASIL DAN PEMBAHASAN \\ Deskripsi Penelitian}

Penelitian ini melibatkan responden sejumlah 84 operator PDDIKTI perguruan tinggi yang tersebar di wilayah Kopertis $\mathrm{V}$ Yogyakarta, dengan mempertimbangkan dari jumlah populasi sejumlah 106 operator perguruan tinggi swasta. Dengan pembagian per wilayah kabupaten/kota di LLDIKTI wilayah V Yogyakarta, sebagaimana tertuang dalam tabel berikut ini :

Tabel 3. Perhitungan Teknik Sampling

\begin{tabular}{llcccc}
\hline No & Kab/kota & Jumlah PTS & Perhitungan & $\begin{array}{c}\text { Jumlah } \\
\text { sampel (\%) }\end{array}$ & Pembulatan \\
\hline 1 & Kota Yogyakarta & 37 & $(37 / 106) \times 84$ & 29,32 & 29 \\
2 & Sleman & 41 & $(41 / 106) \times 84$ & 32,49 & 32 \\
3 & Bantul & 26 & $(24 / 106) \times 84$ & 20,06 & 21 \\
4 & Gunung Kidul & 1 & $(1 / 106) \times 84$ & 0,79 & 1 \\
5 & Kulon Progo & 1 & $(1 / 106) \times 84$ & 0,79 & 1 \\
\hline \multicolumn{7}{r}{} & Jumlah & $\mathbf{1 0 6}$ & & & $\mathbf{8 4}$ \\
\hline
\end{tabular}

Dari tabel di atas terlihat bahwa Kabupaten Sleman sebagai sampel penelitian terbesar dengan 32 PTS dari jumlah populasi 41 PTS, dan kabupaten Gunung Kidul dan Kulon Progo sebagai sampel terendah 1 (satu) karena memang populasinya juga hanya 1 PTS per masing-masing kabupaten. Terjadi perbedaan yang sangat besar jumlah PTS yang ada di Kabupaten Sleman, Kota Yogyakarta, Kabupaten Bantul dibandingkan dengan Kabupaten Gunung Kidul dan Kulon Progo. 
Dilihat dari hasil analisis deskripsi didapatkan bahwa :

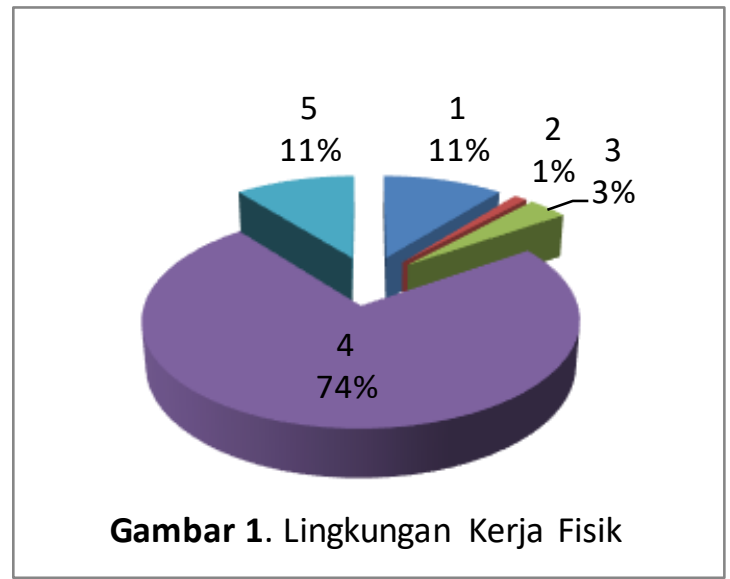

Dimensi penerangan dan pencahayaan meliputi pencahayaan ruang kerja yang sudah memadai, sirkulasi udara yang baik, kebersihan, suhu udara cukup mencukung dan fresh. Dari gambar terlihat bahwa $74 \%$ atau 64 responden menyatakan setuju dengan pernyataan bahwa responden memberikan respon positif terhadap pernyataan ini.

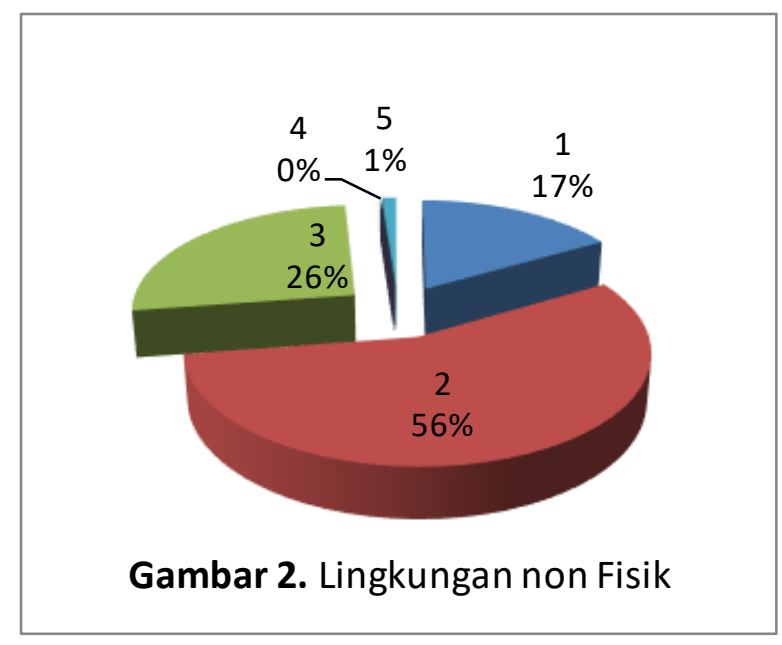

Dari dimensi Lingkungan Kerja non ini meliputi antara lain : hubungan antar karyawan, semangat dan gairah karyawan, rasa kekeluargaan, saling menghargai dan mempercayai dan suasana keakraban menunjukkan $56 \%$ atau 58 responden setuju, 18 responden atau $26 \%$ sangat setuju akan pernyataan dari kuesioner. Artinya lingkungan kerja non fisik responden menyikapi positif atas pernyataan ini.

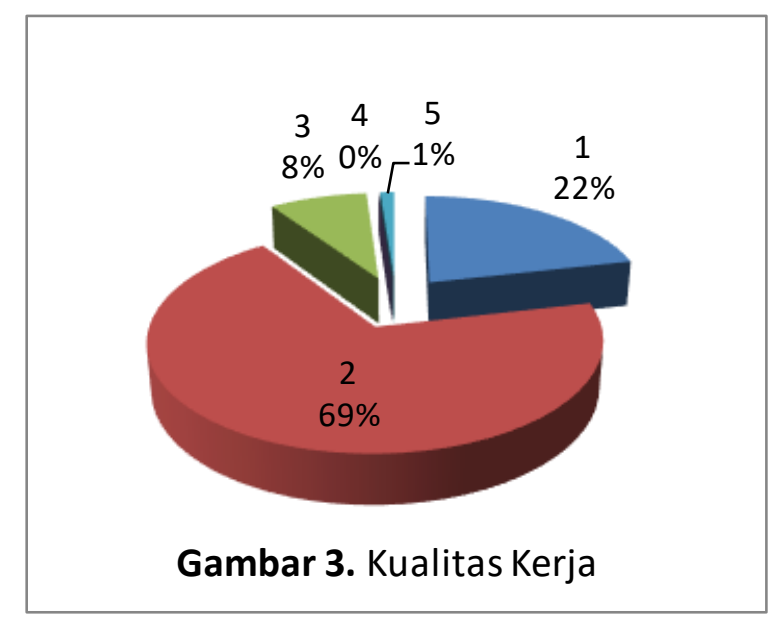


Dimensi Kinerja karyawan ini meliputi kualitas pekerjaan, kuantitas pekerjaan, ketepatan waktu, pengawasan dan hubungan antar pribadi. Gambar menunjukkan bahwa $69 \%$ responden setuju dan $22 \%$ sangat setujua, artinya responden merespon positif atas pernyataan kuesioner.

Untuk mengetahui seberapa besar pengaruh dari variabel independen (bebas) terhadap variavel dependen (terikat) baik secara parsial maupun simultan. Sehingga akan dapat diketahui pengaruh yang terkandung dari kedua variabel bebas (stres kerja, lingkungan kerja) tersebut berpengaruh positif atau negatif. Selain itu analisis ini dapat menjawab pengujian hipotesis yang dirumuskan. Dalam penelitian ini analisis regresi linier berganda digunakan dengan tujuan untuk mengetahui ada tidaknya pengaruh variabel independen yaitu stres kerja dan lingkungan kerja, terhadap variabel independen yaitu kinerja karyawan Operator PDDIKTI di LLDIKTI Wilayah V Yogyakarta.

Hasil perhitungan untuk analisis regresi linear berganda penelitian terangkum dalam tabel berikut :

Tabel 3. Hasil Perhitungan Regresi Linier Berganda

\begin{tabular}{lccc}
\hline \multicolumn{1}{c}{ Variabel } & Koef Regresi & Standard Error & t - hitung \\
\hline Konstanta & 4.837 & 3.847 & 1.257 \\
X1 (Stres Kerja) & 0,196 & 0.035 & 5.528 \\
X2 (Lingkungan Kerja) & 0.240 & 0.32 & 7.574 \\
Adjusted R2 $: \quad 0,453$ & & & \\
F-hitung $\quad: \quad 33,592$ & & & \\
$\mathrm{~N}$ & $: 84$ & & \\
\hline
\end{tabular}

Berdasarkan tabel 3. di atas diperoleh nilai kontanta (a) dan nilai koefisien (b) masingmasing variabel dibentuk persamaan regresi berganda sebagai berikut :

$$
\begin{aligned}
& Y=4,837+0,196 X_{1}+0,240 X_{2}+e \\
& Y=4,837+0,196(\text { Stres Kerja) }+0,240(\text { Lingkungan Kerja })+e
\end{aligned}
$$

Persamaan tersebut mempunyai arti sebagai berikut :

1. Nilai konstanta (positif) 4,837, menunjukkan tanpa ada pengaruh dari kedua variabel independen ataupun faktor lain, nilai variabel kinerja karyawan Operator PDDIKTI LLDIKTI V Yogyakarta mempunyai konstanta sebesar positif 4,837 satuan

2. Nilai Koefisien regresi variabel stres kerja (X1) positif sebesar 0,196 , berarti terdapat pengaruh positif dari variabel stres kerja terhadap kinerja karyawan Operator PDDIKTI Kopertis V Yogyakarta sebesar 0,196, dengan asumsi variabel stres kerja 1 satuan akan meningkatkan kinerja karyawan Operator PDDIKTI LLDIKTI V Yogyakarta sebesar 0,196 satuan

3. Nilai Koefisien regresi variabel lingkungan kerja (X2) positif sebesar 0,240, berarti terdapat pengaruh positif dari variabel lingkungan kerja terhadap kinerja karyawan Operator PDDIKTI Kopertis V Yogyakarta sebesar 0,240 dengan asumsi variabel lingkungan kerja 1 satuan akan meningkatkan kinerja karyawan Operator PDDIKTI LLDIKTI V Yogyakarta sebesar 0,240 satuan.

\section{Pembahasan}

Pengaruh Stres Kerja dan Lingkungan Kerja Secara Simultan Terhadap Kinerja Karyawan Operator PDDIKTI LLDIKTI Wilayah V Yogyakarta

Hasil analisis regresi linier berganda menunjukkan bahwa variabel stres kerja dan lingkungan kerja terhadap kinerja karyawan operator PDDIKTI LLDIKTI Wilayah V Yogyakarta adalah $F_{\text {hitung }}>F_{\text {tabel, }}$ atau 33,592 > 3,11 maka Ho ditolak dan Ha diterima. Jadi kesimpulannya bahwa variabel stres kerja dan lingkungan kerja secara simultan 
berpengaruh terhadap kinerja karyawan Operator PDDIKTI di LLDIKTI Wilayah V Yogyakarta. Dengan nilai koefisien determinasi regresi sebesar 0,435 berarti variabelvariabel tersebut memiliki pengaruh positif. Dua variabel bebas (stres kerja dan lingkungan kerja) memberikan dampak terhadap kinerja karyawan operator PDDIKTI LLDIKTI Wilayah V Yogyakarta sebesar 43,5 \%. Sedangkan sisanya (56,5\%) adalah faktor lain di luar dua variabel bebas tersebut memberikan sumbangan terhadap kinerja operator PDDIKTI LLDIKTI Wilayah V Yogyakarta.

Dengan kata lain selain stres kerja dan lingkungan kerja masih banyak faktor yang mempengaruhi kinerja karyawan operator PDDIKTI LLDIKTI Wilayah V Yogyakarta. Sebagaimana penelitian yang telah dilakukan oleh Dwi Septianto (2014) dengan judul Pengaruh lingkungan lingkungan kerja dan stres kerja terhadap kinerja karyawana studi kasus pa da PT. Pataya Raya Semarang. Hasilnya adalah Lingkungan kerja dan stres kerja berpengaruh signifikan terhadap kinerja karyawan. Sedangkan Tri Diah Ningrum, (2014) dengan judul penelitian Pengaruh stres kerja dan lingkungan kerja terhadap kinerja karyawan PT Makmur Alam Lestari diperoleh hasil penelitian Terdapat pengaruh antara stres kerja, lingkungan kerja fisik dan Lingkungan kerja non fisik terhadap kinerja karyawan. Dari hasil empiris dapat disimpulkan bahwa adanya stres kerja dan lingkungan kerja berpengaruh positif terhadap kinerja karyawan walaupun dari sisi koefisien determinasi sebesar 0,435 artinya masih ada faktor atau variabel lain yang ikut mempengaruhi kinerja karyawan operator PDDIKTI LLDIKTI Wilayah V Yogyakarta.

Pengaruh Stres Kerja dan Lingkungan Kerja Secara Parsial Terhadap Kinerja Karyawan Operator PDDIKTI LLDIKTI Wilayah V Yogyakarta

Hasil analisis regresi berganda memberikan kesimpulan untuk variabel stres kerja terhadap kinerja karyawan Operator PDDIKTI LLDIKTI Wilayah V Yogyakarta adalah $t_{\text {hitung }}$ $>t_{\text {tabel }}$ atau $5.528>1,989$ maka Ho ditolak dan Ha diterima. Artinya bahwa stres kerja berpengaruh terhadap kinerja karyawan operator PDDIKTI LLDIKTI Wilayah V Yogyakarta. Nilai Koefisien regresi variabel stres kerja sebesar 0.196 , berarti variabel stres kerja berpengaruh positif terhadap kinerja karyawan operator PDDIKTI LLDIKTI Wilayah V Yogyakarta.

Hasil penelitian ini sejalan dengan beberapa penelitian terdahulu Siti Nurhendar, (2013) dengan judul Pengaruh stres kerja dan semangat kerja terhadap kinerja karyawan bagian produksi CV. Aneka Ilmu Semarang dengan hasil bahwa Variabel stres kerja mempunyai pengaruh secara signifikan bersama-sama terhadap kinerja karyawan. Penelitian dari Azazah Indriyani, (2013) dengan judul Pengaruh konflik peran ganda dan stres kerja terhadap kinerja perawat wanita rumah sakit (Studi Pada Rumah Sakit Roemani Muhammadiyah Semarang) diperoleh hasil bahwa variabel stres kerja berpengaruh signifikan positif terhadap terjadinya kinerja karyawan. Demikian juga penelitian dari Saina Nur, (2013) dengan judul Konflik, Stres Kerja Dan Kepuasan Kerja Pengaruhnya Terhadap Kinerja Pegawai Pada Universitas Khairun Ternate diperoleh kesimpulan variabel Stres Kerja berpengaruh signifikan terhadap kinerja pegawai. Dari hasil-hasil penelitian di atas menunjukkan bahwa stres kerja berpengaruh positif terhadap kinerja karyawan

\section{Pengaruh Lingkungan Kerja Terhadap Kinerja Karyawan Operator PDDIKTI LLDIKTI Wilayah $\checkmark$ Yogyakarta}

Hasil dari penelitian menunjukkan variabel lingkungan kerja terhadap kinerja karyawanan adalah thitung > ttabel atau $7.574>1,989$ maka Ho ditolak dan $\mathrm{Ha}$ diterima. Jadi dapat disimpulkan bahwa lingkungan kerja berpengaruh terhadap kinerja karyawan operator PDDIKTI Kopertis V Yogyakarta. Nilai Koefisien regresi variabel stres kerja sebesar 0.240 , berarti variabel lingkungan kerja berpengaruh positif terhadap kinerja karyawan operator PDDIKTI LLDIKTI Wilayah V Yogyakarta. 
Hasil penelitian terdahulu menunjukkan Dewi, (2014) dengan judul Pengaruh pelatihan, motivasi kerja dan lingkungan kerja terhadap kinerja karyawan koperasi mahasiswa di Kabupaten Sleman diperoleh hasil bahwa variabel lingkungan kerja berpengaruh terhadap kinerja karyawan. Penelitian dari Agung Nugroho, (2014) dengan judul Pengaruh kepemimpinan, motivasi dan lingkungan kerja terhadap kinerja pegawai negeri sipil Dinas Kehutanan dan Perkebunan Kabupaten Pati. Variabel lingkungan kerja berpengaruh positif dan signifikan terhadap kinerja karyawan. Sementara dari Sartika Hayulinda Halim, (2012) dengan judul Analisis motivasi dan lingkungan kerja terhadap kinerja karyawan pada PT Sinar Galesong Pratama Makasar diperoleh hasil lingkungan kerja berpengaruh positif terhadap kinerja karyawan.

\section{Implikasi Penelitian Stres Kerja Dan Lingkungan Kerja Terhadap Kinerja Karyawan}

Dalam dunia pendidikan tinggi di Indonesia membuat membuat pelaporan ke DIKTI sudah menjadi kewajiban sejak tahun 2002 semester 1 (satu), dalam perkembangannya semakin variasi dan muatannya. Yang awalnya menggunakan sistem aplikasi Epsbed (sistem database) dalam perkembangannya sekarang sudah menggunakan media berbasis internet, yaitu Feeder PDDIKTI.

Masyarakat luas baik calon pengguna lulusan hingga yang pingin menyekolahkan anak-anaknya ke suatu PTS bisa langsung akses ke lamannya DIKTI yaitu di www.forlap.dikti.go.id. Dalam tersebut masyarakat akan bisa menilai tentang keberadaan PTS tersebut bagaimana perijinanannya, akreditasinya, dosen-dosennya, jumlah dan daftar mahasiswanya, dan lebih banyak lagi.

Sumber dari informasi yang masuk di dalam laman DIKTI www.forlap.dikti.go.id adalah dari pelaporannya PTS yang diunggah baik langsung oleh PTS maupun melalui kopertis. Sementara PTS, data yang dikirim ke DIKTI yang muncul di laman www.forlap.dikti.go.id adalah olahan dari operator PDDIKTI di PTS tersebut. Di sini letak dari peran operator PDDIKTI PTS karena apa yang muncul di laman tersebut benar atau salah adalah bersumber pada data yang dikirim oleh PTS, dan PTS yang bertanggung jawab terhadap data tersebut adalah operator PTS. Belum lagi ancaman dari DIKTI bila bila PTS tidak mengirimkan laporannya di laman www.forlap.dikti.go.id yang akan menutup atau membekukan PTS tersebut.

Mengingat peran operator yang sedemikian berat bebannya baik dari sisi kuantitas dan kualitas perkerjaan yang harus jadi dan dilaporkan ke Dikti, waktu pengerjakan yang terbatas, sarana dan prasarana yang harus mendukung dan masih banyak lagi menjadikan beban atau stres kerja bagi para operator PDDIKTI. Untuk itulah koordinator Kopertis selalu mengingatkan agar pimpinan PTS memperhatikan kerja dari operator PDDIKTI dan juga selalu memperhatikan akan kesejahteraannya. Jangan sampai operator didiamkan atau malah dianggap bagian atau unit biasa dari sebuah PTS. Sehingga kinerja dari operator PDDIKTI dapat maksimal dan selesai sebelum batas waktu yang sudah ditetapkan oleh Dikti. Dengan kebijakan pimpinan terhadap operator akan mempengaruhi kualitas kerja dari operator.

Lingkungan kerja juga sangat berpengaruh dengan kinerja operator PDDIKTI. Lingkungan kerja baik fisik maupun non fisik, lingkungan kerja yang mendukung baik itu kenyamanan dalam bekerja, komunikasi hubungan dengan atasan, sesama karyawan akan mendukung kinerja operator. Sumber data yang dikirim oleh unit-unit yang dibutuhkan oleh feeder, misalnya data mahasiswa harus mencari data dari marketing atau registrasi, data dosen harus komunikasi dengan bagian SDM, transaksi akademik harus dengan bagian akademik dan sebagainya. Artinya semua bagian saling berkaitan dan komunikasi dari operator PDDIKTI menjadi komponen penting dalam kinerja karyawan operator. Untuk itu pimpinan PTS perlu menciptakan kondisi yang nyaman baik dari lingkungan kerja fisik maupun non fisik sehingga kinerjanya semakin baik. 
Kinerja karyawan operator harus benar-benar diperhatikan oleh pimpinan PTS, terutama dalam kualitas data yang dikirimkan ke DIKTI, yang akhirnya menjadi sumber informasi atau konsumsi masyarakat luas. Perhatian terhadap beban kerja, kondisi kerja, kariernya, kecukupan fasilitas pedukungnya, dan lingkungan kerja yang nyaman akan menghasilkan kualitas pekerjaan atau kinerja yang baik. Dengan kinerja yang baik dari operator PDDIKTI maka informasi yang diberikan juga kualitasnya baik akan memberikan informasi yang benar dan handal kepada masyarakat melalui DIKTI maupun Kopertis.

\section{KESIMPULAN}

Dari hasil analisis dan pembahasan di atas, maka peneliti dapat menyimpulkan bahwa: (1) Stres kerja dan lingkungan kerja berpengarruh positif terhadap kinerja karyawan operator PDDIKTI LLDIKTI Wilayah V Yogyakarta;(2)Hasil analisis regresi linier berganda menunjukkan bahwa variabel stres kerja dan lingkungan kerja terhadap kinerja karyawan operator PDDIKTI LLDIKTI Wilayah V Yogyakarta secara simultan berpengaruh terhadap kinerja karyawan Operator PDDIKTI di LLDIKTI Wilayah V Yogyakarta. Dengan nilai koefisien determinasi regresi sebesar 0,435 artinya bahwa stres kerja dan lingkungan kerja memberikan dampak terhadap kinerja karyawan operator PDDIKTI LLDIKTI V Yogyakarta sebesar $43,5 \%$. Sedangkan sisanya $(56,5 \%)$ adalah faktor lain di luar dua variabel bebas tersebut memberikan sumbangan terhadap kinerja operator PDDIKTI Kopertis V Yogyakarta.

\section{DAFTAR PUSTAKA}

Ahyani, 1994, Lingkungan kerja dalam perusahaan, Penerbit Citra, Jakarta

Arikunto, S. (2008). Dasar-Dasar Evaluasi Pendidikan. Jakarta: Bumi Aksara

Arikunto, S. (2010). Prosedur penelitian suatu pendekatan praktik. Edisi Revisi 2010. Jakarta: PT. Rineka Cipta.

Azazah Indriyani, 2013, Pengaruh Konflik Peran Ganda dan Stres Kerja Terhadap kinerja Perawat Wanita Rumah Sakit. Tesis Program Magister Manajemen Universitas Diponegoro.

Davis, K., \& Werther, W.,B., Jr., 1996, Human Resoutces and personnel Management. Singapore: McGraw-Hill book, Co.

Dewi S.K.P.(2014). Pengaruh Pelatihan Motivasi Kerja dan Lingkungan Kerja Terhadap Kinerja Karyawan Koperasi Mahasiswa (KOPMA) di Kabupaten Sleman, Tesis, Program Magister Manajemen Universitas Janabadra Yogyakarta.

Dwi Septianto, 2010, Pengaruh Lingkungan Kerja dan Stres Kerja terhadap Kinerja Karyawan PT Pataya Raya Semarang. Universitas Diponegoro, Semarang.

Ghozali, 2009, Model Persamaan Struktural konsep Aplikasi dengan Program AMOS 16.0, Undip Semarang.

Hasan, Iqbal, 2005, Pokok-pokok Materi statistik, Edisi kedua, Bhumi Aksara, Jakarta.

Kementrian Riset, 2015, Teknologi, dan Pendidikan Tinggi Koordinator Perguruan Tinggi Swasta Wilayah V Yogyakarta, Profil PTS di Lingkungan Kopertis V Yogyakarta, Kopertis V Yogyakarta.

Mangkunegara, 2005, Manajemen Sumber Daya Manusia, PT. Refika Aditama, Bandung. 
Mangkunegara, 2007, Manajemen Sumber Daya Manusia Perusahaan, Bandung : Remaja Rosda Karya.

Nuryadi, N., \& Rahmawati, P. (2018). Persepsi siswa tentang penerapan model pembelajaran berbasis proyek ditinjau dari kreativitas dan hasil belajar siswa. Jurnal Mercumatika: Jurnal Penelitian Matematika dan Pendidikan Matematika, 3(1), 53-62.

Nuryadi, S. P., Astut, T. D., Utami, E. S., \& Budiantara, M. (2017). Dasar-Dasar Statistik Penelitian.

Peraturan Pemerintah Nomor 4 tahun 2014, tentang Penyelengaraan Perguruan Tinggi.

Rahmila Sari, Mahlia Mu'is, Nurdjanah Hamid, 2013, Pengaruh Kepemimpinan, Motivasi dan Stress Kerja terhadap Kinerja Karyawan pada Bank Syariah Mandiri Kantor Cabang Makassar, 2011, Jurnal Ekonomi dan Bisnis Universitas Hasanuddin.

Riani, Febri. (2013). "Pengaruh Pengetahuan Audit, Akuntabilitas dan Independensi Terhadap Kualitas Hasil Kerja Auditor". Skripsi Tidak Dipublikasikan Fakultas Enonomi Universitas Negeri Padang.

Sedamayanti, 2009, Sumber Daya Manusia dan Produktivitas, CV. Mandar Maju, Bandung.

Siti Nurhendar. 2007. Pengaruh Stres Kerja dan Semangat Kerja terhadap Kinerja Pegawai Bagian Produksi Pada CV. Aneka Ilmu Semarang. Jurnal Ekonomi dan Bisnis. Volume 7.

SK 034 BAN PT DIKTI, 2002, Tentang Pelaporan Semesteran Program Studi.

Sugiyono, 2010, Statistika untuk Penelitian, Penerbit Alfabeta, Bandung.

Surat Edaran DIKTI Nomor 0543/E.1.2/PL/2015, tentang Feeder DIKTI.

Titi Laras, 2012, Pengaruh Kreativitas dan Inovasi Terhadap Keunggulan Bersaing serta Dampaknya pada Kinerja Perusahaan (Survey Pada Industry Kretif di Kota Bandung), Disertasi, Universitas Padjajaran, Bandung.

Titi Mulyanti Kadarisman, 2007, Pengaruh Stress dan Lingkungan Kerja Terhadap Prestasi Kerja Karyawan pada PT. Tunas Asri Keramik Yogyakarta. Skripsi. Program Studi Manajemen Universitas Mercu Buana Yogyakarta.

Undang-undang Nomor 12 Tahun 2012, tentang Pendidikan Tinggi.

Yatna Nayaputera, 2011, Analisis Pengaruh Kepuasan Kerja dan Stres Kerja terhadap Intensi Turnover Custemet Servis Employee di PT Plaza Indonesia Realty TBK., Tesis., Fakultas Ilmu Sosial dan Politik Program Pasca Sarjana Universitas Indonesia 